\title{
The Opinions of Gifted Students about Leadership Training
}

\author{
Uzeyir Ogurlu ${ }^{1}$ \\ Harvard University, Cambridge, Massachusetts, USA \\ Mehmet Naci Sevim \\ Marmara University, Turkey
}

\begin{abstract}
The aim of this research was to identify gifted middle school students' opinions and suggestions about leadership and leadership education. For this purpose, 65 gifted middle school students who have been attending the Science and Art Center were interviewed by using the focus group. The gifted students were asked openended questions about leadership and leadership training. Qualitative content analysis was employed. The results of the focus group interviews showed that majority of gifted students did not want to be a leader in the future because of some reasons including lack of self-confidence and avoiding taking responsibility. But the majority believed that leadership could be improved through training and wanted to participate in leadership training in schools. The participants suggested some various ways for leadership improvement of students in the schools such as teamwork or giving responsibilities.

Keywords: gifted students, leadership, leadership training, focus group interview
\end{abstract}

\section{The Opinions of Gifted Students about Leadership Training}

Humanity, living as societies, has always been in search for a leader, who is supposed to advance their communities. Therefore, leadership and being a leader have intrigued people who want to lead others. Development of leadership can even be seen in writings of early philosophers, such as Aristo and Plato (Houdyshellm, 2017; Lafer, 2014; Vidergor \& Sisk, 2013). Moreover, developing leadership skills has been considered as a strategic necessity (Fulmer \& Goldsmith, 2000). Not only finding potential leaders but also nurturing their talents to develop in early ages has become vital with the advanced technologies that lead to more connected and dependent countries in today's world (Aydin, 2013; Lee \& Olszewski-Kubilius, 2011). Many definitions of leader and leadership have been made so far in every aspect of life (Sisk, Gilbert \& Gosh, 1991; Sisk, 1993; Tarman, 2016; 2017; Demirhan \& Yücel, 2016). Kouzes and Posner (2007) defined leadership as a relationship between those who desire to lead and those who are willing to follow. Leadership includes the cluster of skills which ensure to see significant problems and solutions to these problems in the world (Michou, Mouratidis, Ersoy, \& Ugur, 2016; Vidergor \& Sisk, 2013). Similar to leaders, gifted people have also attracted societies' attention throughout the history. According to Marland's report (1972), which is regarded as the first formal definition of giftedness, gifted children are capable of high performance include those with showed achievement and potentiality in general intellectual ability, specific academic skills, art and motor skills, creativity and leadership capacity (Stephens, 2008). Although, the association between giftedness and leadership is not necessarily obvious and linear (Lee \& Olszewski-Kubilius, 2006), leadership and giftedness have been discussed together as seen in the first formal definition of giftedness. Also, Karnes and Bean (1996) claimed that most of the research shows a positive link between the leadership and giftedness. Therefore, many researchers support the idea that leadership development and training should be an essential component of the programs for the gifted students (Karnes \& Bean, 2001; Milligan, 2004; Plucker \& Callahan, 2008). However, many researchers have stated that leadership instruction has been ignored in the education of gifted students (Bisland, 2004; Chan, 2000a; Deniz \& Ersoy, 2016; Karnes \& Bean, 1996; Smyth \&Ross, 1999; Sternberg, 2005). According to Kim, Cho, and Jin (2005), leadership abilities of gifted students do not develop spontaneously as they grow up. Without leadership development opportunities, students might limit their potential of leadership in future years (Ersoy \& Ugur, 2015; Mullarkey, Recchia, Lee, Shin, \& Lee, 2005).In addition, they lacked crucial skills to deal with today's competitive global economy (Muammar, 2015). Not only in gifted education, but also in general education at schools, leadership education has been a neglected area (Boyd, 2000; Karnes \& Stephens, 1999). Karnes and Stephens (1999) stated that leadership education should be provided to all students at schools which are the most accessible places for children. Pfeiffer \& Wechsler (2013) supposed that every youth could not be a great leader but any youth can learn new or improve existing skills and attitudes related to leadership if provided effective opportunities and motivation.

There has been an agreement that leadership includes developmental skills than can be taught (Cox \& Hoover, 1992; Covey, 2004; Karnes \& Stevens, 1999; Ersoy, 2015; Parker \& Begnaud, 2004; Roets, 1992; Vidergor \& Sisk, 2013; Kilinc, 2017). Researchers have emphasized the importance of

\footnotetext{
${ }^{1}$ Corresponding author; uzeyir_ogurlu@gse.harvard.edu
} 
developing leadership skills during early years, as it is easier to shape behaviors and competencies during childhood and adolescence compared with adulthood (Avolio \& Vogelgesang, 2011; Gardner, 2011; Martinek, Schilling, \& Hellison, 2006). In the study conducted by The Center for Creative Leadership, ninety percentages of 462 leaders agreed that the best time for leadership education is at the age of 18 , and $\% 50$ of them stated that it is better to get started at the age of 10 (Velsor \& Wright, 2012). Similarly, Komives, Dugan, Owen, Slack, and Wagner (2011) cited that many researchers have stated that knowledge and skills of leadership which students had equipped before the college years are the best indicators to determine their leadership capacity (Antonio, 2001; Dugan, Garland, Jacoby \& Gasiorski, 2008; Dugan \& Komives, 2010; Kezar \& Morriarty, 2000; Smart, Ethington, Riggs \& Thompson, 2002).

Some methods and procedures have been proposed regarding leadership education and training. Firstly, researchers underlined the importance of school atmosphere for students' leadership development (Ersoy, \& Deniz, 2016a; Gardner, 1990; Sternberg, 2008). Fertman and Long (1990) claimed that the teaching of leadership skills could be embedded into the school curriculum. Smith, Smith, and Barnette (1991) cited that many researchers have supported the idea that leadership consists of teachable skills and concepts, that can be developed through proper programs and training during adolescence (Emmerich, 1983; Evans, 1982; Feldhusen ve Kennedy, 1988; Foster, 1981; Franklin, 1983; Gray \& Pfeiffer, 1987; Hensel \& Maher, 1985; Karnes, 1989; Leatt, 1987; Lee, 1989; Porter, 1981; Stiles, 1986; Washburn, 1982). Moreover, discussions and talks about leadership in classrooms can develop leadership skills (Northouse, 2013; Rosebrough \& Leverett, 2011; Slavich 2006; Yurt \& Polat, 2015). Besides, some researchers have found that leadership skills can be given by an active learning approach including activities such as giving a speech in front of a group, writing, discussions, problemsolving, activity organizations, conflicts solving, and team works (Akar, 2016; Ersoy \& Deniz, 2016b; Rosebrough \& Leverett, 2011; Sacks, 2009; Sternberg, 2005; Zimmerman, 2006;). A significant relationship has also been found between participating in extracurricular activities, being members of social organizations and leadership development (Aydin, Ozfidan \& Carothers, 2017; Eccles \& Templeton, 2002; Hancock, Dyk \& Jones, 2012; Van Linden \& Fertman, 1998; Wade 1997). Many researchers have concluded that mentors, role models and other encouraging adults have a substantial effect on the development of leadership skills (Amorose \& Horn, 2000; Arminio et al., 2000; Baisheva et al., 2017; Citamak \& Yigit, 2012; Summers, 2000). Similarly, the importance of educators' role in leadership development has been discussed (Barcelona, Hurd, \& Bruggeman, 2011; McNeil, 2010). For instance, teachers was found to have influence on the development of leadership skills in young children (Fox, Flynn \& Austin, 2015; Fox, 2012). Sacks (2009) investigated students' view on leadership and leadership education in the qualitative study with 42 students, while some of the students stated that leadership could be taught, others said that leadership is inborn. Besides, students considered teachers, administrators, families, and friends as factors which contribute to the leadership development.

There is a common assumption in gifted educators that leaders of the future will more likely come out from gifted students with leadership potential (Davis \& Rimm, 2004; Lee \& OlszewskiKubilius, 2011). Leadership education for gifted students will lead to the growth of leaders who have intellectual and creative potential (Sisk, 1993). Gifted students can develop their leadership potentiality with educational activities which can promote their personal and interpersonal skills (Vidergor \& Sisk, 2013). Many researchers pointed out the efficiency of leadership training programs (Chan, 2000b, 2003; Karnes, Meriweather, \& D'Ilio, 1987; Milligan, 2004; Ogurlu \& Emir, 2014; Smith et al., 1991). For example, the leadership skills development program had a positive effect on both gifted and non-gifted leadership skills (Ogurlu \& Emir, 2014).

Leadership is also accepted as an essential sign of giftedness in Turkish society (Sak et al., 2015). For example, Demirel and Sak (2011) found that the leadership was the most valued talent in Turkish society. However, there is a little known about how to teach or develop leadership abilities in children and youth comparing adults ( Pfeiffer \& Wechsler, 2013). Results from this study can add to the body of literature providing evidence about thoughts about leadership in gifted students. Generally, cognitive and academic skills are considered more important in the identification of gifted children than other skills including leadership or creativity (Jarosewich, Pfeiffer \& Morris, 2002). Also, there is a scarcity of programs aiming to develop their social engagement including leadership, civic responsibility for gifted students compared to programs focusing on their cognitive abilities (Hall \& Quinn, 2014; Lee \& Olszewski-Kubilius, 2011). So, it was expected to increase awareness of leadership skills of gifted studies rather than academic or cognitive skills among teachers and educators with this study. Renzulli and D'Souza (2014) supported the idea of developing these skills at early ages and focusing on direct engagement experiences. For this reason, gifted adolescents were determined for the study group in this study. Berkowitz and Hoppe (2009) stated the importance of allowing gifted children to care for and design an education curriculum. That's why; this study may set light to an education curriculum or school-based leadership training programs for gifted students because this study aimed to investigate 
thoughts and suggestions of gifted secondary school students about leadership and leadership training. The study attempted to test the following questions:

- $\quad$ Are gifted students willing to be a leader in the future?

- What do gifted students think about leadership training at schools?

- $\quad$ Do gifted students want to join leadership training?

training at schools?

What are the suggestions of gifted students about improving leadership

\section{Method}

The study implemented a qualitative research design, with the use of focus groups. This design studies on phenomena that researchers are aware but do not have in-depth and detailed knowledge (Yıldırım \& Şimşek, 2008). It focuses on one's experience on particular occasions (Creswell, 2007). Focus groups are used to understand opinions, beliefs, attitudes, and thought processes that underlie behaviors in a particular subject or events that cannot be revealed with other methods (Krueger \& Casey, 2015; Kuş, 2007). The interaction between participants in the focus group encourages generating and discovering their questions; helps to form group norms; stress common attitudes and priorities (Kitzinger, 1995). Therefore, some random ideas and thoughts may come up during focus group interviews.

\section{Participants}

The sample was chosen based on the convenience sampling method. The main reason for choosing this way was the ease of accessibility (Fraenkel \& Wallen, 2006). The participants of the study were composed of 65 gifted students who were attending to the Science and Art Centers (BILSEM) from grade 6 th to 8 th grades. BILSEM is a state-funded institution providing the special education for primary and secondary school gifted students apart from their usual school time. Assuming that the interaction of gifted students with their peers is essential for their ideas about leadership and leadership training, participants were selected among the students who were attending to BILSEM for at least one year. 22 of the students were girls, and 43 were boys. While 37 of the students were attending to public schools, 28 students were in private schools. 24 students were coming to BILSEM for two years, 16 students for three years and 25 students for four years and more. 40 out of 65 students were continuing to extracurricular activities such as tutoring, sports, and art courses besides BILSEM. Focus group interviews were conducted with seven different groups and each group is composed of between seven and ten students. It was suggested that the number of participants should be between 4 and 10 in the focus group discussion. (Çokluk, Yılmaz, \& Oğuz, 2011).

\section{Instruments}

The data of the study were collected through focus group interviews. During the focus group interview, the researchers formed a semi-structured interview form. Two experts from the field reviewed questions in the form regarding understanding and the content validity. After expert opinions, the researchers did a pilot interview. Questions asked in the focus group discussions are listed below.

- $\quad$ Do you want to be a leader in the future? Why?

- $\quad$ Should there be leadership training in schools? Why?

- Would you like to participate in leadership training? Why?

- How can we improve leadership in schools?

\section{Data Collection}

Seven focus group interviews were conducted. Each group met once, consisting of 7-10 participants in the study. One of the researchers facilitated and moderated the discussion; the second researcher took notes and monitored the process. Each interview took between 40 and 50 minutes, and they were conducted between April - May 2015. Informed consent was obtained from participants. Also, all conversations were also recorded with the voice recorder to ensure consistency between voice and written records. The researcher tried to ask questions in the form of casual conversations. Participants sit around U-shape table, with a given pencil and paper. In the introduction part, the researcher gave a brief overview of the research emphasized that they were free to participate in the interview, and their consent was asked to use the voice recorder during the interviews. All students were encouraged to express their opinions freely. It was observed that the students tended to talk and made comments sincerely during the meetings. During the sessions, the moderator tried to provide an enjoyable atmosphere, to make the group feel at ease, to facilitate the conversation, to avoid domination of the talks and to form the group dynamics. The views of the students were sometimes conflicting, sometimes supporting each other. The answers were often short including one or two sentences, but most of the students were enthusiastic to answer the questions. 


\section{Analysis of the data}

Qualitative content analysis was employed to code and analyze the data. Content analysis tries to make the similar data together by some specific concepts and themes that help better understanding (Yildirim \& Simsek, 2006). The transcripts of the interviews were shown to the students to increase the reliability of the study. After their approval, the researchers began to analyze the data. Two researchers read all transcripts several times to fully understand the content and coded the themes independently to reduce bias, and then they compared their coding. There was a high inter-rater agreement (89\%) in the identification of themes. A percentage indicates the level of agreement among researchers. Researchers reached an agreement on differences through discussion. In the results section, representative quotes from the focus groups, translated from the Turkish, are presented to illustrate the themes. Instead of students' names; the students were listed as $S 1, S 2, S 3 \ldots$ in the quotes.

\section{Results}

The results of the study were shown under subheadings by the research questions: "willingness to be a leader," "leadership training in schools" and "eagerness to participate in leadership training" and "strategies to develop leadership in schools."

\section{Willingness to be a leader}

While most of the gifted students stated that they did not want to be a leader in the future, some students said that they wanted to be leaders in the future. However the differences between groups were not significant. Few students did not express their opinions. The reasons why students were not willing to be leaders revealed were lack of self-confidence and avoiding taking responsibility. Some expressions about lack of self-confidence are given in the following:

S14: I do not want. I think it might be difficult. I am not sure that I can control others when I become a leader. I am afraid that they would not listen to me.

S16: I don't. To me, it is really tough. It's hard for me to make people listen to me.

S20: I wouldn't because it is impossible for me to get the same opinion from a group of individuals and to make everybody happy.

S36: I do not want. I have some leadership qualifications, but I don't have enough confidence.

Also, gifted students were not eager to be a leader because of its responsibility. They thought the burden of leadership was heavy. Some of them didn't like to take responsibility.

S57. I do not want. There are a lot of responsibilities, and I can't take such responsibility.

S39: I wouldn't because it requires a significant responsibility and being perfect. I do not want to take that responsibility. I do not want others to be affected. applauds.

S38: I do not. If you do wrong, you are the one to be blamed; if you do the right, everybody

On the other hand, the reasons why the students would like to be leaders in the future showed that those students preferred taking responsibility and believed that they had some leadership skills and had good deeds for the society. Some of the students' opinions regarding the responsibility are in the following:

S32: I do. I would prefer to lead rather than being led. I also like taking responsibility.

S33: I can be a leader because I can take responsibility

S35: I want because I like taking responsibility.

S45: I would, because I want to take responsibility. I want to be a leader; the one who affects the way things are done and achieved.

Another reason why the students wanted to be leaders in the future was that they believed that they have leadership qualifications. These skills helped students to think about becoming a leader in the future. Some examples are presented:

S22: I can be a leader. I am persuasive. I am the president of the student council in the school. They do whatever I ask them to do. I am a leader from birth.

S63: I would. For example, when playing games, I believe that I can manage well and I can be a good leader.

S15: I like to govern, not to be governed.

S21: I want because people pay attention to what I say and do what I ask.

Some of the eager gifted students believe that they would do good work with the help of their leadership status in the future. They want to help others who were in need. Some statements were shown below:

S9: I do, because I want to make this country a better place.

S12: I'd like to. There are some good things that I can do. 
S62: I want because I want to be a source of hope for people who are in difficult situation.

S67: I want to be a leader to save people from bad people and situations.

\section{Leadership training in schools}

While the majority of the students stated that leadership training should be in schools, there were some students who didn't agree with this opinion. Some students had no idea regarding leadership training. The students who supported leadership training in schools claimed that leadership could be noticed and developed by training and instruction. Some views are below:

S21: There should be. There are a lot of people with leadership skills around me. However, they might not be realized. Individuals with leadership skills might want to be a leader after some training.

S27: Yes. Some students might not have opportunities. During training, their leadership skills can be discovered. Schools can equip these students through leadership training.

S29: I agree with the idea of leadership training in schools because people with leadership potential can develop their skills. Presidents have some traits, such as being patient. However, it's hard to be a leader for someone who does not take any responsibility. It is more appropriate to have it in primary schools because students can continue their future education being aware of where to go. The earlier age they learn, the more knowledge they have.

S43: I think, it is a requirement to improve leadership abilities. This education helps people to notice those skills. However, this instruction should not be given to everybody, but to the ones who are particularly chosen because of his or her skills. Teachers can recognize students with these traits and provide them with this training. However, for others, it would not have any positive effect.

Some gifted students supporting leadership training in schools claimed that leadership training should be elective and based on students' choice. They agreed that the leadership education was not proper for all students. Some students' statements are presented below:

S17: It should be given to students who want it, not to the ones who do not. Students who want it but do not have necessary skills should understand these traits.

S18: It can be an elective without any exam. Otherwise, it would be suffering. Students who are interested in should receive this training and learn what to be done. It should be given only to students who are interested.

S38: It should be given not to everybody, but to selected students. There can be a practical exam. In the beginning teachers, then students can choose students based on their achievement of given tasks.

S46: It can be offered as an elective course. Classes could be for just ten students with a new education system. It can be at the first level and second level. Education should be given according to skill levels, and this system should not be changed every year.

Most of the students who were against leadership training in schools believed that leadership was an inborn trait and cannot be developed with practice. So, leadership training is not useful for students. Accordingly, some statements below were given:

S60: Leadership training should not be provided in schools. Leadership is a genetic trait; it is inborn. For example, there were good and bad leaders in Ottoman Empire. They used to be trained all the time. However, the ones with leadership qualifications became good leaders, and the others couldn't.

S54: It is something that cannot be gained with education. Leadership should change based on circumstances. Giving training just makes people confused. The ones who observe can already do it. The ones who can analyze the situations are already leaders.

S55: There is no need for leadership training. Some people like directing, some like being directed. Training can not change this.

S25: Leadership instruction should not be given in schools. If you are to be a leader, it should be in your character. There is not any separate education for it; it should come out itself.

\section{Eagerness to participate in leadership training}

During focus group meetings, the participants were asked if they would take part in leadership training when they had an opportunity and why. The most of the gifted learners would like to join into leadership training while some of them wouldn't. A few students did not declare any clear opinion in attending leadership training. When the reasons for those students who wanted to the join leadership training are analyzed, gifted students would like to learn if they had leadership skills or potentiality and considered leadership as useful for their future life. Here are some examples of learning their skills were given;

S43: Yes I would like to participate because leadership training can help me to discover the leader inside me.

S27: Yep because I could get leadership skills that I don't have. 
S29: Yes I would like because I want to know if I have leadership skills that are not displayed clearly.

S3: Yes, I may not be able to understand whether or not I have leadership skills. I can see what I could become and what qualities I have.

Furthermore, some of the gifted learners declared that they wanted to join leadership education because it could be beneficial for them in the future. They saw the leadership training as a useful tool for their life. Following are some examples:

S7: My kindergarten teacher once told me that I would become a great leader. I can be a leader when needed. Leadership skills might be needed at some stage of my life in the future

S12: We may not be a great leader, but we can be a leader in what we do. That's why we should get leadership training.

S15: One should get proper training to become a good leader. One should overcome ignorance to become a good leader. I may or may not become a leader, but I would like to participate leadership training.

On the other hand, those learners who didn't want to take part in leadership training said that they wouldn't like to become a leader. They just didn't want to be a leader so they considered leadership training as unnecessary for themselves. Following are some of the examples of the opinions of those learners;

S13: No, because I don't want to become a leader. I have no reason.

S16: I don't want. I have no interest in becoming a leader. It sounds boring. I feel overwhelmed with responsibility training.

S25: I don't. I have no intention of becoming a leader. There is no reason for me to get leadership

S41: I wouldn't. I wouldn't like to be a leader.

\section{Methods of developing leadership at schools}

Gifted students in focus group were asked to list ways of developing leadership, and the statements were categorized according to themes. The most common theme of methods that students offered was group and teamwork activities to build leadership skills. Besides teamwork, they mainly provided giving responsibility, lecturing. There are some statements about teamwork activities below:

S59: Teamwork and taking turns in leadership can help to develop leadership skills.

S18: Group works during classes.

S37: Role play and teamwork can help future leaders to develop their skills

Another method was to give responsibility. They thought that students could develop leadership skills through taking responsibilities.

S56: It can be done by taking responsibility. I can be done by being a class prefect

S45: Learners with leadership skills can be identified and can be given duties such as the class prefect. Therefore they can develop leadership skills.

S39: Children with leadership potential can be given responsibilities so that they can develop leadership skills.

S19: The most essential quality of a leader is courage. We have a free period on Fridays. Learners can be selected to present lessons, and practical applications can be organized to promote courage.

Furthermore, gifted students suggested that special classes would be organized or teachers would give a lecture about the leadership. Following are some of the examples of the opinions of those learners;

S63: Short lessons can be held. If we can't manage teamwork with a teammate that we don't like we can learn to cooperate through time.

S41: It can be an elective subject. Those who aspire to be leaders can select that class.

S31: Specific teachers can take responsibility. The first, the teachers should be trained then teachers can teach leadership skills. If they aren't educated, they may mislead the students.

S21: There may be classes about leadership. We occasionally solve tests. Instead of addressing those tests, students can make a presentation about some topics in the class. The teacher can guide the learner.

S25: There may be classes about leadership. We occasionally solve tests for the exams. Instead of solving those tests, learners can make a presentation about specific topics in class. The teacher can guide the learner.

S31: Specific teachers can be given duties. The first teacher should be trained then teachers can instill leadership skills. If they aren’t experienced, they may mislead the learners. 
Apart from those suggestions, gifted students suggested methods such as role play, games, the introduction of outstanding leaders, clubs, projects, becoming the class head. Also, they offered to integrate leadership training to the curriculum and promote equality in classes to develop leadership skills.

\section{Discussion}

This research aimed to reveal middle school gifted students' views about leadership and leadership training by focus group interview. Many of gifted students in the focus groups indicated that they did not want to be leaders in the future but also some gifted students did. This result is an unexpected that majority of the students wouldn't like to be a leader. Maryland Report (1974) which gave the first official definition of the giftedness defined leadership skill as one of the six areas of giftedness (Matthews, 2004). Also, leadership is accepted as a characteristic of giftedness in Turkey (Ministry of National Education, 2015). This result speculated that having a potential or skill doesn't mean being willing to improve that characteristic or the skill. It is important to take a look at their reasons to understand the unwillingness of these students. The research showed that because of lack of selfconfidence some students didn't want to become leaders. Consistently, some analysis demonstrated that social self-esteem of gifted students was lower than their academic self-esteem (Callahan, Cornell \& Lloyd, 1990; Hoge \& Renzulli, 1993; Lea-Wood \& Clunies-Ross, 1995). Low social self-confidence in gifted students might lead to an unwillingness for leadership which is also a social skill. In addition, selfconfidence decreases in puberty but increases in the late adolescence (Marsh, 1989; McCarthy \& Hoge, 1982). Gifted students in the study were at puberty stage. So, this stage may also affect this result. Moreover, the gifted students wouldn't like to become leaders in the study because of the responsibility of the leadership. On the other hand, the students who were eager to become a leader stated that because they would prefer to take responsibility and love taking responsibility, they wanted to become leaders in the future. The common point of these opposite views was that they already knew that taking responsibility is a necessity for leadership. Also, participants offered taking responsibility as a way of developing leadership skills. Taking responsibility is one of the critical components of leadership. Having this kind of contradictory thoughts in the research may result from characteristics developmental age in which students were. Adolescents are in search of a personal identity, through an intense exploration of individual values, beliefs, and aims. In this period, adolescents may not be sure of their characteristics and may have uneasy feelings about themselves (Aydın, 2005). On the other side, gifted students who wanted to be leaders in the future believed that they had leadership skills.

Another result of the research showed that the majority of the gifted students felt that there should be leadership training in the schools. Students thought that the leadership could be identified and improved by training. As mentioned in the introduction section, many researchers in the field agree that leadership is a developmental skill and can be enhanced by training in gifted students. Kim et al. (2005) indicated that leadership did not improve in gifted students through ages and emphasized the importance of leadership training. Some of the students mentioned that leadership comes from birth and does not change by training, so leadership training is not necessary. Similarly, Sacks (2009) indicated that some students believed that leadership could be learned and some thought that it is inborn in his qualitative study with 42 primary and middle school students. Vidergor and Sisk (2013) cited that the idea of everybody can be a leader is an incorrect belief, but leadership potential can be improved with the appropriate training and guidance (Birk, 2010; Smith, 2010). Students who wanted to participate in leadership training stated that they wanted training to discover their leadership potential and skills. This result might show that gifted students were aware of the importance of leadership training. The majority of the students in the research stated that they want to participate in leadership training whereas some would not like to join. In the study students who were not eager to become a leader wouldn't prefer to attend to leadership training. It is expected that someone who does not want to become a leader does not want to participate in leadership training.

As far as students' suggestions about leadership training are concerned, their offers were similar to the literature in the field. The majority of the students offered group or teamwork activities for leadership training. Another way which students supported to improve leadership was giving responsibility and task. Also, they said special courses or teachers' lectures were relevant for leadership training. Besides these suggestions, role-playing and games, introducing outstanding leaders, club activities, projects, class presidency, curriculum chapters in the courses and the idea of equality were in the list that gifted student made for leadership development. Researchers claimed that leadership could be improved by active learning approach which includes public speaking, writing, discussions, problemsolving, activity organizations, conflict resolution, and teamwork (Rosebrough \& Leverett, 2011; Rosch \& Meixner, 2011; Sacks, 2009; Sternberg, 2005; Zimmerman, 2006). Karnes and Stephens (1999) suggested that instead of a separate curriculum, students can develop leadership knowledge and skills 
with extra activities to the existing curriculum. Similarly, Rosebrough and Leverett (2011) pointed that students can develop leadership skills better when instruction in the classroom is inspiring rather than knowledge-based.

As a result, most of the gifted students didn't want to become a leader because of some reasons, on the other hand, there were more students were thought to be a leader in the future. Gifted students supported the leadership training to some extent and provided some ideas how to develop leadership skills in schools. The results of the study have some educational implications. Firstly, leadership training is a necessity for gifted students. Students who had low self-confidence and thought that leadership skills could not improve by training verifies the importance of providing leadership opportunities including leadership training for gifted students. Also, developing students' leadership skills contribute to improving self-esteem (Ornstein, Levine, Gutek, \& Vocke, 2011). Besides academic subjects, social skills like leadership or self- esteem skills should be taken into consideration in gifted programs. Longitudinal research has shown that gifted students have not always accomplished becoming leaders in adulthood (Lee \& Olszewski-Kubilius, 2011). That's why; the results of this research can guide administrators and researchers in developing leadership training programs for gifted students. In addition, students' suggestions may be helpful for administrators and educators in understanding what kind of leadership opportunities students wanted. Students' views may also enlighten teachers about leadership training in the classrooms because teachers may have difficulties to develop their leadership competencies in their classes (Mullarkey et al. 2005).

\section{Limitations and Recommendations}

Although this research may help to open new windows about leadership training for gifted students, it has some limitations. An explicit limitation of this study was the limited numbers of the sample size. Also, the results of the current study have to be taken with caution because of the convenience sampling of the participants in Turkey. So, further research in Turkey and different countries should use random sampling to see cultural differences. Also, in the focus interview groups, only 6-8 grade gifted students were included. Future research should take a wider range of classes. Another limitation of the inability to the generalizability of findings was that gifted students in the study had attended a particular educational setting for gifted students. So, other gifted students who do not have any special support should be involved in the sample. Quantitative methods, observation, and longitudinal follow-up should be included to support the qualitative evaluations in further studies. Leadership is a multifaceted ability (Lee \& Olszewski-Kubilius, 2011). That's why; future research should draw the attention to different dimensions of leadership development in gifted students.

\section{References}

Akar, C. (2016). Investigating the students' perceptions of the democratic values of academicians. Journal of Social Studies Education Research, 7(1), 96-139. doi:10.17499/jsser.49601

Amorose, A.J. \& Horn, T.S. (2000). Intrinsic motivation; Relationship with collegiate athlete's gender, scholarship status and perceptions of their coaches' behavior. Journal of Sport \& Exercise Psychology, 22(1), 63-84.

Arminio, J.L., S. Carter, S. E. Jones, K. Kruger, N. Lucas, J. Washington, N.Young, \& Scott, A. (2000). Leadership experiences of students of color. NASPA Journal, 37(3), 496-510.

Aydin, H. (2013). Students and teachers' perceptions on technology enhanced Turkish language learning environment in Turkey. Educational Research and Reviews, 8(13), 986-996.

Aydin, H , Ozfidan, B , Carothers, D . (2017). Meeting the Challenges of Curriculum and Instruction in School Settings in the United States. Journal of Social Studies Education Research, 8 (3), 7692. Retrieved from http://dergipark.gov.tr/jsser/issue/32449/360844

Avolio, B. J., \& Vogelgesang, G. (2011). Beginnings matter in genuine leadership development. In S. E. Murphy, \& R. J. Reichard (Eds.), Early development and leadership: Building the next generation of leaders (pp. 179-204). New York: Psychology Press/Routledge.

Aydin, B. (2005). Çocuk ve ergen psikolojisi. [Child and adolescent psychology] Ankara: Atlas Yayınları.

Baisheva, M , Golikov, A , Prokopieva, M , Popova, L, Zakharova, A, Kovtun, T . (2017). The potential of folk tabletop games in the development of the intelligence and creativity of children. Journal of Social Studies Education Research, 8 (3), 128-138. Retrieved from http://dergipark.gov.tr/jsser/issue/32449/360847

Barcelona, R. J., Hurd, A. R., \& Bruggeman, J. A. (2011). A competency-based approach to preparing staff as recreation and youth development leaders. New Directions for Youth Development, $130,121-139$. 
Berkowitz, M., \& Hoppe, M. (2009). Character education and gifted children. High Ability Studies, 20(2), 131-142.

Bisland, A. (2004). Developing leadership skills in young gifted students. Gifted Child Today, 27, 2427.

Boyd, B. (2000). Youth for community action: Leadership for inner-city youth. ERIC Document Reproduction Service No. ED446199

Callahan, C., Cornell, D., \& Lloyd, B. (1990). Perceived competence and parent-adolescent communication in high-ability adolescent females. Journal for the Education of the Gifted, 13,256-269.

Chan, D. W. (2000a). Developing the creative leadership training program for gifted and talented students in Hong Kong. Roeper Review, 22(2), 94-97.

Chan, D. W. (2000b). Assessing leadership among Chinese secondary students in Hong Kong: The use of the Roets Rating Scale for Leadership. Gifted Child Quarterly. 44, 115-122.

Chan, D. W. (2003). Leadership skills training for Chinese secondary students in Hong Kong: Does training make a difference? Journal of Secondary Gifted Education, 14(3), 166-174.

Citamak, Y. \&Yigit, H., I. (2012). From Student's Table to Teacher's Desk. International Journal of New Trends in Arts, Sports \& Science Education, 1(2), 1-7.

Çokluk, Ö.,Yılmaz, K. \& Oğuz, E. (2011). Nitel bir görüşme yöntemi: odak grup görüşmesi. [A qualitative interview method: focus group interview] Kuramsal Eğitimbilim, 4 (1), 95-107.

Covey, S.R. (2004). The 8th habit. New York: Free Press.

Cox, D., \& Hoover, J. (1992). Leadership when the heat's on. New York: McGraw-Hill.

Creswell, J. W. (2007). Qualitative inquiry and research design: Choosing among five approaches (2nd ed.). Thousand Oaks, CA: Sage Publications.

Davis, G. A. \& Rimm, S. B. (2004). Education of the gifted and talented (5th ed) Boston: Allyn \& Bacon.

Demirel, Ş., \& Sak, U. (2011). Yetenek hiyerarşisi: üstün yetenek türlerinin toplumsal değerleri üzerine bir araştırma [Talent hierarchy: A research study on the social value of talent types] Türk Üstün Zekâ ve Egitim Dergisi, 1(1), 61-76.

Demirhan, G., \& Yücel, C. (2016). A Prediction for Teacher Commitment: Effects of Managerial Style, Burnout and Demographics, Research in Social Sciences and Technology, (I)1, 24-43.

Deniz, M., \& Ersoy, E. (2016). Examining the Relationship of Social Skills, Problem Solving and Bullying in Adolescents. International Online Journal of Educational Sciences, 8(1), 1 -7.

Eccles, J., \& Templeton, J. (2002). Extracurricular and other after-school activities for Youth. Review of Education, 26, 113-180.

Ersoy, E. (2015). Assessment of Adolescent Perceptions on Parental Attitudes on Different Variables. Journal of Education and Training Studies, 3(5), 165-176.

Ersoy, E., \& Ugur, H. (2015). The Relationship between Students' Self-esteem and Parental Attitudes in Turkish Society. The Anthropologist, 21(1-2), 112-119.

Ersoy, E., \& Deniz, M. E. (2016). Psychometric Properties of the Gifted Students' Coping with Anger and Decision Making Skills Scale. Journal of Education and Practice, 7(15), 121-128.

Ersoy, E., \& Deniz, M. E. (2016). Üstün Yetenekli Çocukların Öfkeyle Başa Çıkma ve Karar Verme Becerilerinin Bazı Değişkenler Açısından İncelenmesi. İlköğretim Online, 15(3), 1017-1030.

Fertman, C. I., \& Long, J. A. (1990). All students are leaders. School Counselor, 37 (5), 391-396.

Fox, D. (2012). Teachers' perceptions of leadership in young children (Doctoral dissertation). University of New Orleans Theses and Dissertations.

Fox, D. L., Flynn, L., \& Austin P. (2015). Child leadership: Teachers' perceptions and influences, Childhood Education, 91(3), 163-168, DOI: 10.1080/00094056.2015.1047306

Fraenkel, J.R., \& Wallen, N.E. (2006). How to design and evaluate research in education. New York: McGraw-Hill.

Fulmer, R., \& Goldsmith, M. (2000). The leadership investment: How the world's best organizations gain strategic advantage through leadership development. New York: Amacon.

Gardner, H. (2011). Positioning future leaders on the good work track. In S. E. Murphy, \& R. J. Reichard (Eds.), Early development and leadership: Building the next generation of leaders (pp. 255-272). New York: Psychology Press/Routledge.

Gardner, J. W. (1990). On leadership. New York, NY: Free Press.

Hall, N. \& Quinn, R. (2014). Parental Involvement at the High School Level: Parents' Perspectives. Journal of Ethnic and Cultural Studies, 1(1), 13-21.

Hancock, D., Dyk, P. H., \& Jones, K. (2012). Adolescent involvement in extracurricular activities: Influences on leadership skills. Journal of Leadership Education, 11(1), 84-101.

Hoge, R. D., \& Renzulli, J. S. (1993). Exploring the link between giftedness and self-concept. Review 
of Educational Research, 63, 449-465.

Houdyshellm, M. (2017). Academic integrity in an emerging democracy: How university students in a former Soviet Republic balance achievement and success in education. Journal of Ethnic and Cultural Studies, 4(1), 14-25.

Jarosewich, T., Pfeiffer, S. I., \& Morris, J. (2002). Identifying gifted students using teacher rating scales: A review of existing instruments. Journal of Psychoeducational Assessment, 20, 322336.

Karnes, F. A., \& Bean, S. M. (1996). Leadership and the gifted. Focus on Exceptional Children, 29(1), $1-12$.

Karnes, F. A., \& Bean, S. M. (2001). Methods and materials for teaching the gifted. Waco, TX: Prufrock Press.

Karnes, F. A., \& Stephens, K. R. (1999). Lead the way to leadership education. Digest, 64(8), $62-65$.

Karnes, F. A., Meriweather, S., \& D'Llio, V. (1987). The effectiveness of the leadership studies program. Roeper Review, 9(4), 238-241.

Kilinc, E. (2017). Review of Modernising school governance: Corporate planning and expert handling in state education. New York, NY: Routledge. 172 pp., ISBN-9781138787476..Research In Social Sciences And Technology, 2(2). Retrieved from http://ressat.org/index.php/ressat/article/view/327

Kim, M., \& Cho, S., \& Jin, S. (2005). Grade and gender differences in creativity and leadership and the relationship of the two abilities. The Korean Journal of Educational Psychology, 19, 799-820.

Kitzinger, J. (1995). Qualitative research. Introducing focus groups. British Medical Journal (BMJ), 311, 299-302.

Komives, S. R., Dugan, J. P., Owen, J. E., Slack, C., \& Wagner, W. (2011). The handbook for student leadership development (2nd ed.). San Francisco, CA: JosseyBass.

Kouzes, J. M., \& Posner, B. Z. (2006). The leadership challenge (4th ed.). San. Francisco, CA: JosseyBass

Krueger, R. A., \& Casey, M. A. (2015). Focus groups: A practical guide for applied research (5th ed.). Thousand Oaks, CA: Sage Publications.

Kuş, E. (2007). Nicel-nitel araştırma teknikleri [Qualitative-quantitative research methods]. Ankara: Anı Yayıncilık.

Lafer, S.(2014). Democratic Design for the Humanization of Education. Journal of Ethnic and Cultural Studies, 1(1), 6-12.

Lea-Wood, S. S., \& Clunies-Ross, G. (1995). Self-esteem of gifted adolescent girls in Australian schools. Roeper Review, 17, 195-197.

Lee, S. Y., \& Olszewski-Kubilius, P. (2006). The emotional intelligence, moral judgment, and leadership of academically gifted adolescents. Journal for the Education of the Gifted, 30(1), 29-67.

Lee, S. Y., \& Olszewski-Kubilius, P. (2011). Leadership development and gifted students. In R. J. Levesque, (Ed.) Encyclopedia of adolescence (pp. 1557-1565). New York: Springer

Marsh, H. W. (1989). Age and sex effects in multiple dimensions of self-concept: Preadolescence to early adulthood. Journal of Educational Psychology, 81, 417-430.

Martinek, T., Schilling, T., \& Hellison, D. (2006). The development of compassionate and caring leadership among adolescents. Physical Education \& Sport Pedagogy, 11, 141-157.

Matthews, M. S. (2004). Leadership education for gifted and talented youth: A review of the literature. Journal for the Education of the Gifted, 28(1), 77-113.

McCarthy, J. D. \& Hoge, D. R. (1982). Analysis of age effects in longitudinal studies of adolescent self-esteem. Developmental Psychology, 18, 372-79.

McNeill, B. (2010). The important role non-parental adults have with youth learning leadership. Journal of Extension, 48 (5), 1-4.

Michou, A., Mouratidis, A., Ersoy, E., \& Uğur, H. (2016). Social achievement goals, needs satisfaction, and coping among adolescents. Personality and Individual Differences, 99, 260265.

Milligan, J. (2004). Leadership skills of gifted students in a rural setting: Promising programs for leadership development. Rural Special Education Quarterly, 23 (1), 16-22.

Ministry of National Education (2015). Bilim ve Sanat Merkezleri Yönergesi. Retrieved April 29, 2011 from http://orgm.meb.gov.tr/meb_iys_dosyalar/2015_09/18101802_bilimvesanatmerkezleriynerges i.pdf.

Muammar, O. M. (2015). The differences between intellectually gifted and average students on a set of leadership competencies. Gifted Education International, 31(2), 142-153. 
Mullarkey, L. S., Recchia, S. L., Lee, S. Y., Shin, M. S., \& Lee, Y. J. (2005). Manipulative managers and devilish dictators: Teachers' perspectives on the dilemmas and challenges of classroom leadership. Journal of Early Childhood Teacher Education, 25(2), 123-129.

Northouse, P. G. (2013). Leadership theory and practice (6th ed.). Thousand Oaks, CA: Sage Publications.

Ogurlu, U., \& Emir, S. (2014). Effects of a leadership development program on gifted and non-gifted students' leadership skills. Eurasian Journal of Educational Research (EJER), 55, 223-242.

Ornstein, A., Levine, D., Gutek, G., \& Vocke, D. (2011). Foundations of Education. Belmont, CA: Wadsworth.

Parker, J. P., \& Begnaud, L.G. (2004). Developing creative leadership. Portsmouth, NH: Teacher Ideas Press.

Pfeiffer, S. I., \& Wechsler, S. M. (2013). Youth leadership: A proposal for identifying and developing creativity and giftedness. Estudos de Psicologia (Campinas), 30(2), 219-229.

Plucker, J. A. \& Callahan, C. M. (2008). Critical issues and practices in gifted education: What the research says. Waco, TX: Prufrock Press Inc.

Renzulli, J. S., \& D'Souza, S. (2014). Intelligences outside the normal curve: Co-cognitive factors that contribute to the creation of social capital and leadership skills in young people. In J. A. Plucker \& C. M. Callahan (Eds.), Critical issues and practices in gifted education: What the research says (pp. 343-362). Waco, TX: Prufrock Press.

Roets, L. (1992). Leadership: A skills training program. Des Moines: Leadership Publishers Inc.

Rosch, D., \& Meixner, C. (2011). Powerful pedagogies. In S. R. Komives, J. P. Dugan, J. E. Owen, C. Slack, \& W. Wagner (Eds.) The handbook for student leadership development (pp. 307-337). San Francisco, CA: Jossey-Bass.

Rosebrough, T. R., \& Leverett, R. G. (2011) Transformational teaching in the information age: Making why and how we teach relevant to students. Alexandria, VA: Association for Supervision and Curriculum Development.

Sacks, R. (2009). Natural born leaders: An exploration of leadership development in children and adolescents. Ottawa, Canada: Heritage.

Sak, U., Ayas, M.B., Sezerel, B.B., Öpengin, E., Özdemir, N.N., \& Gürbüz, S.D. (2015) Türkiye'de üstün yeteneklilerin egitiminin elestirel bir değerlendirmesi [Gifted and talented education in Turkey: Critics and prospects] Türk Üstün Zekâ ve Egitim Dergisi, 5(2), 110-132.

Sisk, D. A. (1993). Leadership education for the gifted. In K. A. Heller, F. J. Mönks, \& A. H. Passow (Eds.), International handbook of research and development of giftedness and talent (pp. 491505). New York: Pergamon.

Sisk, D., Gilbert, P., \& Gosh, R. (1991). Developing leadership in a multicultural society. Gifted Child Today, 14(4), 60-61.

Slavich, G. M. (2006). Transformational teaching. In T. Zinn, B. Saville, \& J. Williams (Eds.), Essays from excellence in teaching (Vol. 5). Washington, DC: American Psychological Association.

Smith, D. L., Smith, L., \& Barnette, J. (1991). Exploring the development of leadership giftedness. Roeper Review, 14(1), 7-12.

Smyth, E., \& Ross, J. A. (1999). Developing leadership skills of pre-adolescent gifted learners in small group settings. Gifted Child Quarterly, 43(3), 204-211.

Stephens, K. R. (2008). Applicable federal and state policy, law and legal considerations in gifted education. In S. I. Pfeiffer (Ed.), Handbook of giftedness in children: Psychoeducational theory, research, and best practices. New York: Kluwer Academic/Plenum Publishers.

Sternberg, R. (2008). The WICS approach to leadership: Stories of leadership and the structure and process that support them. The Leadership Quarterly, 19, 360-371.

Sternberg, R. J. (2005). WICS: A model of giftedness in leadership. Roeper Review, 28(1), 37-44.

Summers, P.P. (2000). The roots of leadership. Psychology: A Journal of Human Behavior, 37(1), 27 36.

Tarman, B. (2016). Innovation and education. Research in Social Sciences and Technology, 1(1), $77-$ 97.

Tarman, B. (2017). Editorial: The Future of Social Sciences. Research in Social Sciences and Technology, 2(2). Retrieved from http://ressat.org/index.php/ressat/article/view/329

Van Linden, J. A., \& Fertman, C. I. (1998). Youth leadership: A guide to understanding leadership development in adolescents. San Francisco: Jossey-Bass.

Velsor, E.V., \& Wright, J. (2012). Expanding the leadership equation: Developing next-generation leaders. Retrieved from Center for Creative Leadership. Alınan yer: http://www.ccl.org/leadership/pdf/research/ExpandingLeadershipEquation.pdf 
Vidergor, H. E., \& Sisk, D. A. (2013). Enhancing the gift of leadership: Innovative programs for all grade levels. Ulm, Germany: International Center for Innovation in Education.

Wade, R. C. (1997). Community service learning. New York, NY: State University of New York Press.

Yildirim, A., \& Şimşek, H. (2008). Sosyal bilimlerde nitel araştırma yöntemi [Qualitative methods in social sicences] (6th Ed.). Ankara: Seçkin Yayıncılik.

Yurt, E., \& Polat, S. (2015). The effectiveness of multiple intelligence applications on academic achievement: A meta-analysis. Journal of Social Studies Education Research, 6(1), 84-122. doi:10.17499/jsser.75161

Zimmerman, B. J. (2006). Enhancing students' academic responsibility and achievements: A socialcognitive self-regulatory account. In R. J. Sternberg, \& R. Subotnik (Eds.), Optimizing student success in school with the other three Rs: Reasoning, resilience, and responsibility (pp. 179197). Greenwich, CT: Information Age. 